Journal of the Scholarship of Teaching and Learning, Vol. 19, No. 1, February 2019, pp. 29-40.

doi: 10.14434/josotl.v19i1.26783

\title{
Maintaining High-Impact Bridge Programming at Scale
}

\author{
Vincent Windrow \\ Middle Tennessee State University \\ Vincent.windrow@mtsu.edu \\ Ryan Korstange \\ Middle Tennessee State University
}

\begin{abstract}
This paper uses Middle Tennessee State University's MT Scholars Academy, an extended early arrival program targeting first-year students who are classified as at-risk by a variety of measures, as a case study for demonstrating the effectiveness of AASCU's Re-Imagining the First-Year (RFY) initiative. In particular, this case study demonstrates the implications of RFY's foundational assumption that successful practices are known well in student success literature and need to be enacted. The case study demonstrates the scholarship which undergirds the program and describes a series of decision points that have been encountered as these research proven strategies have been put into practice. The current iteration of the program is also described thoroughly, and its results for student success are articulated.
\end{abstract}

Keywords: student success, first-year retention, summer bridge, first-year experience, re-imagining the first-year.

In higher education, programs tend to become stale or even ineffective after a number of years. This article will provide a case study of Middle Tennessee State University's (MTSU) MT Scholars Academy (SA) - a continuously evolving summer bridge turned early arrival program informed by the work of Astin (1998), Tinto (1993, 2012), and Schlossberg (2008) - which is aimed towards improving the retention, progression, and graduation of students who are typically considered "high risk." The changes made to the program have refined the implementation of research-informed best practices for student success and have adapted general principles into the specific context of our campus community.

Tinto (2006) points out that increased knowledge about why students leave universities "does not tell institutions, at least directly, what they can do to help students stay and succeed" (p. 6). He goes on to suggest that, "the regrettable fact is that many good ideas are not well implemented or implemented fully. In other cases, even when fully implemented, many programs do not endure" (p. 9). These observations are substantially similar to those that undergird the Reimagining the First Year (RFY) initiative. This initiative, formed by the American Association of State Colleges and Universities (ASSCU) in 2016, is a conglomeration of 44 higher educational institutions who have agreed that the national college graduation rate which hovers near 55\% is not satisfactory and who have committed to enacting research based best practices to affect drastic change in retention, persistence, and completion rates. As AASCU official George Mehaffy suggested in his remarks at the RYF launch event, "we have a large body of research that demonstrates that we know what to do to improve student success for all students, particularly low income, first generation, students of color" (Mehaffy, 2015 , p. 3). In his view, low retention and completion rates are not a result of a "knowledge problem" but of an "implementation problem" (p. 3).

This research explores the successful implementation of the MT Scholars Academy. The program has evolved and developed over the years since its pilot phase and is now institutionalized and moving towards full-scale implementation. It has survived staffing departures, changes in institutional demographics, changes in structure, and changes in university policy. Along the way, the 
program has developed and strengthened increasingly significant institutional partnerships and has maintained vitality and effectiveness. The overarching question is why? What factors combine to create the success of this program? And further, which of these factors can be abstracted and applied to other student success initiatives? This program embodies the benefits of effectively implemented, and research backed first-year success initiatives advocated by RFY program, and the $81 \%$ average first-year retention rate for program participants over the past four years demonstrates the effectiveness of the RFY approach of enacting effective practices at scale.

\section{Context: What We Know About First-Year Student Success}

Research into the factors that affect student retention has come a long way since the 1970's, and its development has been summarized well already (Tinto, 2006). Retaining first year students requires effective transition to college expectations in both social and academic domains of college life (Mannan, 2007). Within each domain the overarching criteria that affect retention is student involvement/engagement (Tinto, 2001; Upcraft, Gardner, \& Barefoot, 2005). Yet, the precise definition of what effective involvement/engagement involves and requires is rather nebulous. Certainly, as Kuh (2008) observes, high-impact practices (HIP's) are those that require students to spend considerable time and effort on educationally significant tasks. However, what constitutes considerable time, considerable effort, and the boundaries of what should be classified as educationally significant tasks are all open to debate.

At a basic level, important structural differences exist between high school and college expectations. According to Braxton and Hirschy (2005) these differences require that students are integrated into both the structural and normative standards of the institution. Some of the transitions that students need to make are expected or clearly presented, while others are more covert and exist as a part of the so-called hidden curriculum (Smith, 2013). Failing to recognize and adapt to differences between the institutional and student expectations results in an experience that Kidwell (2010) describes as a both "purgatorial zone" that is typified by "academic hazing." Clearly, this type of experience is to be avoided at all costs. Thus, effective first-year programming must identify as many of the differences between high school and college and communicate those differences clearly to students. A complicating factor is the divergent experiences of individual students, but the complexity is unavoidable. Large elements of transition happen in both the academic and social domains.

\section{Academic Factors}

In considering the academic factors related to first-year student success, it is immediately clear that what students need is to figure out how to learn in the college environment, which is significantly different than their high school experience. Erickson, Peters, and Strommer (2006) summarize the difference between high school and college classes by suggesting that "courses are larger and seem less personal; the structure is looser and the support less evident; expectations seem less clear and evaluation is less frequent" (p. 8). Of course, students notice the difference almost immediately - but knowing how to adapt their learning to meet the change is another story. The result is often inaction. More than $75 \%$ of first-year students report studying less than 10 hours per week, while only 5\% report studying more than 20 hours a week (Eagan, et al., 2016). In addition, applying the academic patterns used in high school is often ineffective. Research into effective learning conditions has demonstrated that effort and time correlate to learning at a high rate (Dunlosky, et al., 2013), and that the most effective study strategies are the least used by students (Blaisman, Dunlosky, \& Rawson,

Journal of the Scholarship of Teaching and Learning, Vol. 19, No. 1, February 2019. josotl.indiana.edu 
2017). Not surprisingly, this reduction in effort decreases student learning in college (Arum \& Roksa, 2011; Blaich \& Wise, 2011).

\section{Social Factors}

Students also need to effectively transition to social aspects of postsecondary education. A number of significant changes happen during the transition to college. Students often leave established support structures (composed of family and friends) and experience increased flexibility and autonomy. Many choices are available to college freshman which were not options in high school. For example, students in college can choose not to attend class. In addition, they often have access to more alternative forms of entertainment than they did in high school. The difficulty of adjusting to these increased social freedoms is compounded by the fact that students are in class less per week than they were in high school, which results in more unregulated time.

A number of overlapping social factors have bearing on a student's retention. Several of these factors measure a student's relationship to their educational institution, including: satisfaction (Krumrei-Mansuso, et al., 2013), engagement (Kahu, 2013), self-efficacy (Davidson \& Beck, 2007), institutional fit (Denson \& Bowman, 2015), relationship with teachers (Haugenauer \& Volet, 2014), social integration (Brooman \& Darwent, 2014), student attachment (Wilson \& Gore, 2013), and connectedness (Jorgenson, et al., 2018). In addition, family support (Feenstra, et al., 2001) and relationships with peers (McCabe, 2016 [connecting in college]) also affect student success and retention. Students adjust to each of these factors at different rates and in different measures, but the overall result is that a student who adjusts well feels as if they belong at the university and is retained.

\section{"High-Risk" Students}

The term "high-risk" is increasingly understood as problematic because of its connotations of student deficiency. However, in general, "high-risk" students are those for whom their "academic background (academic preparation), prior performance (low high school or first-semester college GPA), or personal characteristics may contribute to academic failure or early withdrawal from college" (Pizzolato, 2003, p. 798). The personal characteristics that contribute to 'high-risk' status include: "raised in a single-family household, low-income, first-generation, demonstrate poor academic performance" (Smith, 2013). Also, it is clear that institutional barriers affect each of these risk categories differently, and so affect the retention, persistence, and graduation of these students. These students are typically understood to experience several deficits - in comparison with other lower-risk students. In particular, they seem to have lower levels of family support (Choy, 2002), are less academically prepared, and lack the type of cultural capital and experience that are valued in educational contexts (Choy, 2002). However, becoming a college student is an incredibly important part of the "possible self-achievement process" for these students (Pizzolato, 2003, p. 799).

The aforementioned areas of risk relate directly to student retention in several significant ways. Engle and Tinto (2008) demonstrate that first-generation students are four times more likely to leave institutions of higher education without a degree. Hodges-Payne (2006) argues that low income families do not understand the benefits of college degrees, and so dropout is more pronounced amongst that demographic. However, it is important to recognize that low income students work during college "because of their obligations to support other responsibilities they may have outside of college" (Petty, 2014, p. 258). In addition, Hicks (2003) demonstrates that first-generation students are psychologically less prepared for college. The result is that "overcoming intimidation and obstacles are skills that first-generation students lack but must learn in order to survive in college" (Petty, 2014, p. 262).

Journal of the Scholarship of Teaching and Learning, Vol. 19, No. 1, February 2019. josotl.indiana.edu 
In light of this research, institutions have developed various transition programs with the expressed goal of improving student persistence and retention by ameliorating the myriad difficulties inherent to the first-year of college. In particular, two related programs-bridge programs and firstyear experience programming-will be described herein, because the MT Scholars Academy is a combination of both programming models.

\section{Bridge Programming}

Bridge programs have their origin in the federal Upward Bound program. Originally these programs were constructed to assist students in preparing for and achieving college enrollment (Kallison \& Stader, 2012), but they have come to exist as remediation programs, aiming to assist students in navigating the many transitions associated with the first year of college. Typically, these bridge programs contain academic instruction, tutoring, study skills instruction, mentoring/advising, and information about college financial aid and application (Gullatt \& Jan, 2003). Effective bridge programs focus on establishing trusting relationships between students and staff, addressing areas of content weakness, providing college survival skills, hearing from previously successful college students, and receiving quality career and academic counseling (Engle, et al., 2006).

\section{First-Year Experience/Seminar Courses}

First-Year Experience courses take a variety of forms and play many different functions in the landscape of higher education. Skipper (2017) notes that from a national perspective there are four types of first-year seminar courses: a) extended orientation, b) academic seminar with uniform content, c) academic seminar with variable content, and d) hybrid, and argues that first-year seminars incorporating some or all of these conditions could be classified as high-impact (p. 8). The impact of successful first year seminar programs is notable, resulting in their designation as high impact practices (HIP's) (Kuh, 2008). Effective first year seminar courses work to ameliorate the difficulties of a student's transition to college. Cuseo and his colleagues (2007) suggest that students must learn four essential things in their first-year of college: (1) active involvement, (2) utilization of campus resources, (3) social interaction/collaboration, and (4) self-reflection. These principles form the backbone of an effective FYS course.

Thus, it is clear that any program wishing to increase student retention needs to consider both the academic and social factors that influence student success and retention. Further, these programs must prioritize student involvement, the use of campus resources, the creation of relationships amongst students and various university stakeholders, and must enable and provide opportunity for self-reflection. Finally, it must be mentioned that a student's initial experience with the university is incredibly significant (Woosley, 2003). These are the 'best practices' that have been put into place as the theoretical foundation for the MT Scholars Academy and will be demonstrated in more detail in the following case study.

\section{MT Scholars Academy}

The MT Scholars Academy is a first-year initiative, aimed towards improving the retention, progression, and graduation of students who are typically considered "high risk." The program commenced in 2005 with 20 students utilizing best practices of such established summer bridge programs as the ones at University of South Carolina, University of California - San Diego, and Indiana University-Purdue University Indianapolis (IUPUI). At that time, the program was tailored to increasing the academic success of students of color (Hart, 2016). In the early years, much of the

Journal of the Scholarship of Teaching and Learning, Vol. 19, No. 1, February 2019. josotl.indiana.edu 
program's activities centered on both self-esteem and self-efficacy. Its four major components: academic, social services, career, and research were designed to promote the students' self-awareness, critical thinking abilities, social network, and a sense of belonging (Kenett \& Reed, 2009). While the initial contact occurred during six weeks in the summer term, when students took two college courses (a 3-credit First Year Experience [FYE] and a 3-credit communications course), weekly meetings were held throughout the first year of transition. Moreover, the participants were expected to remain active in the program throughout their matriculation. This program design offered students a head start towards accomplishing their academic goals.

Success of the first cohorts as measured by retention led to the growth of the program. The following table shows the growth in enrollment and the 1-year retention rate of the program participants. Retention is defined as a student enrolling during the fall semester of the following year.

\section{Table 1: MT Scholars Academy Enrollment \& Retention}

$\begin{array}{lll}\text { Year } & \text { Enrollment } & \text { SA 1-year Retention } \\ 2010 & 23 & 69.5 \% \\ 2011 & 28 & 96.4 \% \\ 2012 & 30 & 76.6 \% \\ 2013 & 32 & 84.4 \% \\ 2014 & 115 & 85.2 \% \\ 2015 & 165 & 83.6 \% \\ 2016 & 312 & 78.8 \% \\ 2017 & 351 & 78.0 \%\end{array}$

As currently formed, the MT Scholars Academy consists of both an academic curriculum and co-curricular activities. The 2017 Scholars Academy cohort was made up of 352 participants. Of these, $59.9 \%$ were female, and $40 \%$ were male; $58.52 \%$ identified as black or African American, $3.98 \%$ as Hispanic, $3.98 \%$ as having two or more ethnicities, and $32.67 \%$ as white. In addition, $63.92 \%$ were first generation college students, whereas $36.07 \%$ were not. The average composite ACT score for the cohort was 20.97, with the following subset averages: English 21.49; Math 20.13; Reading 22.19; Science 21.48. In addition, 117 of the students had earned some college credit before enrolling in the program, and these students earned an average of 9.09 credits earned, though it should be mentioned that eight students earned more than 20 credits, with one particularly industrious student earning 50 credits before matriculating to college.

The classroom curriculum is an adaptation of our First Year Experience course, which is focused on the development of college-appropriate success skills. Students enroll in the FYE course during the fall semester, though a variety of academic topics are presented to students first during nine intensive sessions in the summer (time management, the expectations of college level learning, effective study practices, building relationships on campus, etc.). The students' application of these skills is supported by regular class and programmatic meetings during the semester. Co-curricular activities include several meetings with Student Affairs staff, attending MTSU sporting events, attending first year student programming, and touring campus buildings and facilities.

\section{Decision Points}

As the program has developed, it has faced challenges. The full goal is to serve 500 students per year while maintaining the identity of the program that has made it successful. Through the development of the program, several decision points have influenced its current iteration.

Journal of the Scholarship of Teaching and Learning, Vol. 19, No. 1, February 2019. josotl.indiana.edu 
In 2010, the manner in which the university is funded was changed dramatically. The Tennessee state legislature passed the Complete College Tennessee Act (CCTA) of 2010, which had as one of its provisions a funding formula model that moved state funding from enrollment to progression and completion. One of the implications of this change was that students who took summer classes would not be counted as first-time freshmen in the fall semester. Because of the priority that retention of first-time freshmen plays in the funding formula, it was imperative that the students in this program be counted as first time freshmen during the fall semester. Thus, the program was transitioned from a traditional bridge program taking place in the middle of the summer, into an early arrival program taking place in the two weeks before the start of the fall semester. The program remains residential because it is clear that transitioning to independent living is one of the many transitions that students need to successfully navigate to ensure their institutional success.

Changing the duration of the program and its timing required also that the curriculum be revamped. It was no longer possible to offer students the opportunity to take two full classes for credit. In the first years of the relocated program, students took non-credit seminars in three areas: study skills, basic math, and basic science. The goal was to give students the skills necessary to be successful not only in college generally, but to have a refresher on basic content in Math and Science, classes that have high DFW rates on campus. However, because the classes were not for credit, they did not have the expected effect. Many students were not engaged in the workshops, and several did not find value in the offerings creating problems of students skipping the sessions. The current iteration of the program devotes the intensive instructional time in the summer sessions to academic skills development. In the summer term of the program, students develop a strategy for their success in the coming year. This work is submitted on the first day of the fall term, and provides the foundation for the remainder of the course which focuses on supporting students as they apply their strategy to their first semester in college.

Another decision point deals with staffing. Initially, the program was led by the university's chief diversity officer. Later, due to tightening budgets during the national recession that began in 2008, the program was relocated to Student Affairs and was housed in the Office of Intercultural and Diversity Affairs. When the program's director received an appointment in Academic Affairs in 2013, the program followed him and is now housed in the Office of Student Success. One of the major benefits of the program for students is the connections they make with university staff and faculty. When the program was smaller, these benefits were easier to confer - the administrator in charge of the logistics and implementation knew each student personally, as did several high-level administrators and the faculty who taught in the program. All the students met with their academic advisors as well. As the program grew past 100 students, the quality of those personal relationships was threatened. Faculty expectations were re-written to include individual meetings with students throughout the semester to help troubleshoot and advise students more comprehensively. In addition, support staff were added to divide responsibilities between the logistics of program development, assessment, and recruitment of students and the more 'boots on the ground' functional leadership of the summer institute and academic year programming.

In addition to the evolution of the professional staff component, peer mentoring has also become an integral part of the program. In 2010, when the program was relocated to the Division of Student Affairs, the decision was made to incorporate peer mentors into the structure. It was determined that a peer mentor was needed for every seven participants. The peer mentors received compensation including complimentary residential hall accommodations and free breakfast, lunch, and dinner during the program's summer duration. Over the last eight years, peer mentor training has been added as have book bags, and the lead peer mentor position. The number of peer mentors has risen to 48 for the 2017 cohort.

Journal of the Scholarship of Teaching and Learning, Vol. 19, No. 1, February 2019. josotl.indiana.edu 
One final decision point is worth discussing, that of intentional campus partnerships. Creating quality programming to ensure the success of 'high-risk' students is a big job, which benefits from wide collaboration of various stakeholders. Since 2010, the program has had a residential option. That is, while students who live off campus can commute to the program and are welcomed to participate, the vast majority of the participants reside in dormitories. Those residential students receive several benefits from a collaborative relationship with Housing and Residential Life including familiarity with dorm life, relationship-building with resident hall assistants and other staff, and early exposure to residential hall policies and programming. Another noted benefit is that the program's residential participants avoid the hectic move-in days at the start of the fall semester when three thousand other residents move in.

As the academic component of the program developed, partnership was required with various academic departments including University Studies (the area housing our first-year seminar course), English, Math, and Science. Fostering these partnerships enabled the creation of quality curriculum across the disciplines covered in the program. Collaborative partnerships are also developed with various support services across campus. Because student use of tutoring correlates both with increased GPA and retention gains (Cooper, 2010; Reinheimer \& McKenzie 2011), the program partnered with the campus tutoring center to expose students to the benefits of tutoring. This partnership resulted in intentional daily tutoring sessions during the Summer Institute. These sessions were led by peer mentors. In addition, efficient, convenient, and responsive libraries are correlated with student success (Scott et al., 2008), so students were regularly encouraged to use the library for independent study.

Not all of the decision points are behind us. At present, we are working to allow students the opportunity to develop essential areas of academic skills in the summer before their first full term in college, particularly in Math, English, and Science. All too frequently, academically rigorous general education courses challenge students and threaten their sense of belonging at the university, or within their chosen degree path. Our current curricular development efforts are aimed at providing opportunities for students to refresh or develop essential skills in these areas in order to then be more successful in theses foundational general education courses. In addition, we are looking at ways of more systematically supporting students who enroll in SA through the sophomore transition and into the completion of their degree.

Lastly, there is a modicum of concern that the MT Scholars Academy has peaked in terms of size and its ability to continue to produce retention rates above $80 \%$ as it has in prior years. Although the program's success continues to outpace that of non-participants, interest in the program's potential point of diminishing returns has been expressed. Those questions were raised as reactions to the 2016 cohort's below $80 \%$ retention rate. The 2016 cohort, which was then the program's largest before the 2017 cohort surpassed it, experienced a couple of unexpected gyrations that perhaps impacted its success rate.

One, its persistence rate, measured by the percentage of students who return for the spring semester following their first fall semester, was lower than expected and needed. The first-year retention rate goal for each cohort is $85 \%$. In order to reach that goal, it has been concluded that the persistence rate must be near 95\%. However, the 2016 cohort's persistence rate was $90.8 \%$, which did not leave much room for the slippage that takes place following the spring semester.

Two, the program lost two key administrators at critical times. The staff person who handled the administrative and other customer service tasks including room reservations, daily and weekly reports, interfacing with the participants, and office coordination left the university in May 2017. Perhaps more impactful was the departure of the staff person who led the program's recruitment and retention efforts. That person was integral in establishing the tone, setting expectations, meeting with the cohort, and providing intrusive leadership and daily management. When that person departed the

Journal of the Scholarship of Teaching and Learning, Vol. 19, No. 1, February 2019. josotl.indiana.edu 
university in June 2017 in the middle of our 2016 retention efforts and 2017 recruitment efforts, there was a considerable shift in effort, energy, and prospects for both cohorts.

As aforementioned, one of the strengths of the program is that it is constantly been reviewed for opportunities to increase its ability to aid student success. Therefore, several enhancements have been added over the years. A recent and compelling example of this commitment is the decision to commence the FYE course in the summer and extend it throughout the fall semester. With regard to persistence the 2017 cohort produced a $94.9 \%$ persistence rate. That is, $94.9 \%$ of the 2017 cohort who entered the program in summer 2017 and enrolled at MTSU in fall 2017 were enrolled for the spring 2018 semester. As for retention, the 2017 cohort was retained at 78\% rate. While the retention rate goal for the program remains at $80 \%$, program participants were still retained at a higher rate $(78 \%)$ than were students who entered the university the same fall semester yet did not participate in the program $(75 \%)$.

\section{Conclusion}

The RFY project operates from the assumption that the field of student success research has developed to the point where effective policies and programs are clear. Mehaffy pointed this fundamental starting point in his speech at the launch of the program. In his words, "when I say WE know what to do, I really mean the field knows what to do" (p.3). But, Mehaffy did not stop there, he continued by suggesting that, "each of us, on our own campuses, knows some things but few of us have a broad enough view to know all of the most promising practices. We each grasp a different part of the problem" (p. 3). To these observations can be added the conclusion from the National Commission on Higher Education Attainment, which argues "access alone is not enough. For all students, traditional or not, offering access without a commitment to help students complete college degrees is a hollow promise" (NCHEA, 2013). Helping students, particularly underrepresented and underprepared students, make meaningful progress to their degree and to find success in college is of paramount importance.

The MT Scholars Academy forms a test case for each of these observations. The preceding review has demonstrated that since the establishment of the program, university officials have intentionally developed the curricular and co-curricular offerings both in response to larger changes in the landscape of higher education, and in order to make the program more effective for the individual students enrolled. In terms of access, enrolment has seen exponential growth while keeping the costs of the program passed onto the students low. More significant though have been the developments in the program components. These developments work to make sure that the program is not a hollow promise of increased student success, but rather carries through and benefits the students who enroll. In this way, we have relied heavily on the things "we know" in student success literature. But, no research demonstrated program has been copied whole cloth. Rather, we have put bits of several programs into practice. The combination of these programs benefit the students enrolled both in this program, and at our university. Mehaffy was not wrong when he asserted that individual universities have particular knowledge of practices leading to student success. Moreover, this individual knowledge is extremely beneficial in other contexts. But, it must be applied and translated to the new institutional context rather than just replicated.

There are many issues that arise when one applies national research to a local context. These issues are not insurmountable, but it must be borne in mind that successful programs are rarely 100\% transferrable. Rather, emendation is necessary. In this case, we have faced a number of decision points where circumstances external to the success research have necessitated decisions and changes to the program which were unexpected. However, by approaching these decision points carefully, involving a wide range of institutional stakeholders in the decision-making process, and maintaining the place

Journal of the Scholarship of Teaching and Learning, Vol. 19, No. 1, February 2019. josotl.indiana.edu 
of primary impact proven by research, we have been able to create a dynamic program that benefits both the students and the university. RFY's methodology is key in this process. To progress one must avoid analysis paralysis, build a program on the basis of what is demonstrated to work as seen in national research, and then emend the program as various decision points arise to maintain the benefit, but to fit the local context.

\section{References}

Astin, A. W. (1998). The changing American college student: Thirty-year trends, 1966-1996. The Review of Higher Education, 21(2), 115-135.

Blasiman, R., Dunlosky, J., \& Rawson, K. (2017). The what, how much, and when of study strategies: comparing intended versus actual study behaviour. Memory, 25(6), 784-792.

Braxton, J. M., \& Hirschy, A. S. (2005). Theoretical developments in the study of college student departure. In A. Seldman (Ed.), College student retention: Formula for student success (pp. 61-87). Westport, CT: ACE Praeger.

Brooman, S., \& Darwent, S. (2013) Measuring the beginning: a quantitative study of the transition to higher education, Studies in Higher Education, 39(9), 1523-1541.

Choy, S. P. (2002). Access and persistence: Findings from 10 years of longitudinal research on students (Report No. EDO-HE-2002-02). Washington, DC: American Council on Education.

Cooper, E. (2010) Tutoring center effectiveness: The effect of drop-in tutoring. Journal of College Reading and Learning, 40(2), 21-34.

Cuseo, J., Fecas, V. S., \& Thompson, A. (2007). Thriving in college and beyond: Research based strategies for academic success and personal development. Dubuque, IA: Kendall/Hunt.

Davidson, W. D., \& Beck, H. P. (2006-2007). Survey of Academic Orientation scores and persistence in college freshmen. Journal of College Student Retention: Research, Theory \& Practice, 8, 297-305.

Denson, N., \& Bowman, N. (2015). The development and validation of an instrument assessing student-institution fit. Assessment \& Evaluation in Higher Education, 40(8), 1104-1122.

Dunlosky, J., Rawson, K. A., Marsh, E. J., Nathan, M. J., \& Willingham, D. T. (2013). Improving Students Learning with Effective Learning Techniques: Promising Directions from Cognitive and Educational Psychology. Psychological Science in the Public Interest, 14(1), 4-58.

Eagan, K., Stolzenberg, E. B., Zimmerman, H. B., Aragon, M. C., Sayson, H. W., \& Rios-Aguilar, C. (2016). The American freshman: National norms fall 2016. Los Angeles, CA: Higher Education Research Institute.

Engle, J., Bermeo, A., \& O’Brien, C. (2006). Straight from the source: What works for firstgeneration students. Washington, DC: The Pell Institute for the Study of Opportunity in Higher Education.

Journal of the Scholarship of Teaching and Learning, Vol. 19, No. 1, February 2019. 
Engle, J., \& Tinto, V. (2008). Moving beyond access: College success for low-income, firstgeneration students. Pell Institute for the Study of Opportunity in Higher Education. Retrieved from http://www.eric.ed.gov/PDFS/ED504448.pdf.

Erickson, B. L. S., Peters, C. B., Strommer, D. W., \& Erickson, B. L. S. (2006). Teaching first-year college students. San Francisco, CA: Jossey-Bass.

Feenstra, J. S., Banyard, V. L., Rines, E. N., \& Hopkins, K. R. (2001). First-year students' adaptation to college: The role of family variables and individual coping. Journal of College Student Development, 42, 106-113.

Gullatt, Y., \& Jan, W. (2003). How do pre-collegiate academic outreach program impact collegegoing among underrepresented students? Boston, MA: Pathways to College Network Clearinghouse.

Hart, J. (2016). MTSU boosts efforts in minority student retention, graduation. MTSU News, p 6. Retrieved from http://www.mtsunews.com

Haugenauer, G, \& Volet, S. (2014). Teacher-student relationship at university: An important yet under-researched field. Oxford Review of Education, 40(3), 370-388.

Hicks, T. (2003). First-generation and non-first-generation pre-college students' expectations and perceptions about attending college. Journal of College Orientation and Transition, 11(1), 5-17.

Hodges-Payne, T. (2006). Perceptions of first-generation college students: Factors that influence graduate school enrollment and perceived barriers to attendance (Doctoral Dissertation). Retrieved from ProQuest dissertations and Theses database. (UMI No. 3223320).

Jorgenson, D., Farrell, L., Fudge, J., \& Pritchard, A. (2018). College connectedness: The student perspective. Journal of the Scholarship of Teaching and Learning, 18(1), 75-95.

Kahu, E. (2011) Framing student engagement in higher education, Studies in Higher Education, 38:5,758-773.

Kallison, J., \& Stader, D. (2012). Effectiveness of summer bridge programs in enhancing college readiness. Community College Journal of Research and Practice, 36(5), 340-357.

Kennett, D.J., \& Reed, M.J. (2009). Factors influencing academic success and retention following a $1^{\text {st }}$-year post-secondary success course. Educational Research and Evaluation, 15(2), 153-166.

Kidwell, K. (2005). Understanding the first-year experience. The Clearing House: A Journal of Educational Strategies, Issues, and Ideas, 76(6), 253-256.

Krumrei-Mancuso, E., Newton, F., Kim, E., \& Wilcox, D. (2013). Psychosocial Factors Predicting First-Year College Student Success. Journal of College Student Development, 54(3), 247-266.

Journal of the Scholarship of Teaching and Learning, Vol. 19, No. 1, February 2019. 
Kuh, G. D. (2008). High-impact educational practices: What they are, who has access to them, and why they matter. Report from the Association of American Colleges and Universities.

Mannan, M. A. (2007). Student attrition and academic and social integration: Application of Tinto's model at the University of Papua New Guinea. Higher Education, 53, 147-165.

McCabe, J. (2016). Connecting in college: How friendship networks matter for academic and social success. Chicago, IL: University of Chicago Press.

Mehaffy, G. (2016, February 4). Welcome to the Re-Imagining the First Year of Colelge Project. Presented at the Launch of the Re-Imagining the First Year of College (RFY) AASCU Academic Affairs Winter Meeting, Austin, TX. Retrieved from http://www.aascu.org/RFY/MehaffySpeech.pdf

National Commission on Higher Education Attainment. (2013, January 23). An open letter to college and university leaders: College completion must be our priority. Washington, DC: American Council on Education. Retrieved from http://www.acenet.edu/newsroom/Pages/NationalCommission-on-HigherEducation-Attainment.aspx

Petty, T. (2014). Motivating first-generation students to academic success and college completion. College Student Journal, 48(2), 257-264.

Pizzolato, J. (2003). Developing self-authorship: Exploring the experiences of high-risk college students. Journal of College Student Development, 44, 797-812.

Reinheimer, D., \& McKenzie, K. (2011). The impact of tutoring on the academic success of undeclared students. Journal of College Reading and Learning, 41(2), 22-36.

Schlossberg, N. (2008). Overwhelmed: Coping with life's ups and downs ( ${ }^{\text {nd }}$ ed). Lanham, MD: M. Evans.

Scott, G., Shah, M., Grebennikov, L, \& Singh H. (2008). Improving student retention: A university of western Sydney case study. Journal of Institutional Research, 14(1), 9-23.

Skipper, T. L. (2017). What makes the first-year seminar high impact? An exploration of effective educational practices. Columbia, SC: University of South Carolina, National Resource Center for the First-Year Experience and Students in Transition.

Smith, B. (2013). Mentoring at-risk students through the hidden curriculum of higher education. Landham, MD: Lexington Books.

Tinto, V. (1993). Leaving college: Rethinking the causes and curses of student attrition (2nd ed.). Chicago, IL: University of Chicago Press.

Tinto, V. (2006). Research and practice of student retention: What next? Journal of College Student Retention: Research, Theory \& Practice, 8(1), 1-19.

Tinto, V. (2012). Completing college: Rethinking institutional action. Chicago, IL: University of Chicago Press. 
Windrow and Korstange

Upcraft, M., Gardner, J., \& Barefoot, B. (2005). Challenging and Supporting the First-Year Student: A Handbook for Improving the First Year of College, San Francisco: Jossey-Bass.

Wilson, S., \& Gore, J. (2013). An attachment model of university connectedness, The Journal of Experimental Education, 81(2), 178-198

Woosley, S. A. (2003). How important are the first few weeks of college?: The long term effects of initial college experiences. College Student Journal, 37, 201-207.

Journal of the Scholarship of Teaching and Learning, Vol. 19, No. 1, February 2019. josotl.indiana.edu 